University of Wollongong

Research Online

Faculty of Business - Papers (Archive)

Faculty of Business and Law

2008

Paragons and dysfunctions: a report on the first Asia workshop on institutional analysis organised by the ronald coase institute

Alfredo R. Paloyo

University of Wollongong, apaloyo@uow.edu.au

Follow this and additional works at: https://ro.uow.edu.au/buspapers

Part of the Business Commons

Research Online is the open access institutional repository for the University of Wollongong. For further information contact the UOW Library: research-pubs@uow.edu.au 


\title{
Paragons and dysfunctions: a report on the first Asia workshop on institutional analysis organised by the ronald coase institute
}

\author{
Abstract \\ In January 2008, the Ronald Coase Institute conducted the First Asia Workshop on Institutional Analysis, \\ in partnership with the Lee Kuan Yew School of Public Policy and the Asia Competitiveness Institute of \\ the National University of Singapore. This report highlights the general theme of the workshop: that well- \\ functioning institutions are fundamental to development. This is shown by summarising two studies \\ presented at the workshop and by contrasting two countries from Southeast Asia, i.e., the Philippines and \\ Singapore.

\section{Keywords} \\ report, first, asia, workshop, institutional, paragons, analysis, dysfunctions, organised, ronald, coase, \\ institute \\ Disciplines
Business

\section{Publication Details} \\ Paloyo, A. R. (2008). Paragons and dysfunctions: a report on the first Asia workshop on institutional \\ analysis organised by the ronald coase institute. European Business Organization Law Review, 9 (4), \\ 657-669.
}




\title{
European Business Organization Law Review
}

http://journals.cambridge.org/EBR

Additional services for European Business Organization Law Review:

Email alerts: $\underline{\text { Click here }}$

Subscriptions: Click here

Commercial reprints: $\underline{\text { Click here }}$

Terms of use : $\underline{\text { Click here }}$

\section{Paragons and Dysfunctions: A Report on the First Asia Workshop on Institutional Analysis Organised by the Ronald Coase Institute}

\author{
Alfredo R. Paloyo
}

European Business Organization Law Review / Volume 9 / Issue 04 / December 2008, pp 657 - 669

DOI: 10.1017/S1566752908006575, Published online: 17 February 2009

Link to this article: http://journals.cambridge.org/abstract_S1566752908006575

How to cite this article:

Alfredo R. Paloyo (2008). Paragons and Dysfunctions: A Report on the First Asia Workshop on Institutional Analysis

Organised by the Ronald Coase Institute. European Business Organization Law Review, 9, pp 657-669 doi:10.1017/

S1566752908006575

Request Permissions : $\underline{\text { Click here }}$ 


\title{
Paragons and Dysfunctions:
}

\section{A Report on the First Asia Workshop on Institutional Analysis Organised by the Ronald Coase Institute}

\author{
Alfredo R. Paloyo* \\ 1. Introduction. \\ 2. Faculty and participants \\ 659 \\ 3. Selected presentations \\ 3.1 Privatisation and bureaucracy in post-communist Russia..........................66 661 \\ 3.2 \\ Growth and democracy \\ 662 \\ 4. \\ Conclusion ..... \\ 664
}

\begin{abstract}
In January 2008, the Ronald Coase Institute conducted the First Asia Workshop on Institutional Analysis, in partnership with the Lee Kuan Yew School of Public Policy and the Asia Competitiveness Institute of the National University of Singapore. This report highlights the general theme of the workshop: that wellfunctioning institutions are fundamental to development. This is shown by summarising two studies presented at the workshop and by contrasting two countries from Southeast Asia, i.e., the Philippines and Singapore.
\end{abstract}

Keywords: institutional economics, Philippines, Singapore, democracy, bureaucracy, Ronald Coase Institute.

\section{INTRODUCTION}

In just roughly 50 years since it declared independence, ${ }^{1}$ Singapore has skyrocketed to first-world status and has become the only Southeast Asian country in the top 25 of the Human Development Index. ${ }^{2}$ What makes this achievement incredible

* Thanks are due to the Ronald Coase Institute for the fellowship and to the Ruhr Graduate School in Economics (RGS Econ) for the financial assistance. Correspondence: RGS Econ, Hohenzollernstr. 1-3, 45128 Essen, Germany; e-mail: paloyo@rwi-essen.de.

1 Singapore separated from Malaysia on 9 August 1965.

2 The Human Development Index is a measure of well-being published by the United Nations Development Programme. It uses a weighted average of life expectancy at birth, adult 
is that the initial conditions under which Singapore started its ascent to the top were just as challenging as those that were observed to prevail in other developing countries which have thus far remained underdeveloped. When it gained independence from Malaysia, the tiny city-state was reeling from a mass unemployment crisis and the socio-cultural balance was delicate.

The economic advancement of Singapore is widely attributed to the effectiveness of its political leadership. From the beginning, then Prime Minister Lee Kuan Yew successfully tackled a laundry list of problems with the help of a strong public sector that was practically immune to corruption (Neo and Chen, 2007). The institutions - or 'rules of the game', as defined by Douglass North (1993) that materialised under the direction of its political establishment made Singapore a paragon worthy of emulation by other countries. Like a lighthouse to which wandering ships impute navigational guidance, Singapore exemplified, for the citizens of the developing world, what is possible if only the poor institutional dynamics prevailing in their societies improve and allow each of their ships to safely reach port. Even now, it serves as a 'Camelot' that 'possesses an ethos that subverts the mediocrity and mendacity that otherwise pervade many aspects of social and intellectual life' (de Dios, 2007) elsewhere. ${ }^{3}$

It is therefore no surprise that the Ronald Coase Institute (RCI) chose Singapore as the venue for the First Asia Workshop on Institutional Analysis. In Singapore, institutions just work; for example, in the annual 'Doing Business' report of the World Bank, Singapore outperformed all other countries overall, while the Philippines, in contrast, ranked 140th. ${ }^{4}$ Appropriately, the RCI partnered with the Lee Kuan Yew School of Public Policy and the Asia Competitiveness Institute of the National University of Singapore in bringing to reality its first workshop conducted in Asia. Without a doubt, institutional change could have profound impacts on the development of economies in this region. It is commendable that the RCI has brought institutional analysis closer to scholars working in Asia and the rest of the developing world, because these are the same people whose access to 'local knowledge' can contribute richly both to the advancement of the discipline of New Institutional Economics itself and to the economic and social progress of their own countries.

literacy rate, gross school enrollment ratio and gross domestic product per capita at purchasing power parity. In the 2007 edition, Singapore is ranked 25th, between Greece (24th) and South Korea (26th). The closest Southeast Asian country is oil-rich Brunei, ranked 30th.

3 This remark was made by Emmanuel S. de Dios, Dean of the University of the Philippines School of Economics (UPSE). He describes how Raul V. Fabella, his immediate predecessor, thinks of the UPSE. It applies equally well to the case of Singapore and its relationship with its neighbours.

4 The World Bank publishes an annual report, 'Doing Business', that 'provides objective measures of business regulations and their enforcement across 181 economies and selected cities at the subnational and regional level.' 
The rest of the report is structured as follows. Section 2 provides an overview of the participants and faculty. Section 3 contains a brief summary and discussion of two selected presentations, one by faculty (3.1) and the other by students (3.2). A discussion can be found in the last section (4).

\section{FACULTY AND PARTICIPANTS}

At the outset, it was obvious that the workshop benefited from the diversity of the participants. With 21 scholars from all corners of the globe, the substance of the perspectives brought into the presentations and discussions was almost tangible. Participants came from Burkina Faso, China, Indonesia, Japan, Peru, the Philippines and Venezuela to name a few countries. The locations of the academic institutions where the scholars obtained or are currently pursuing their training increased the geographic scope of the workshop to include France, Germany, South Korea, the UK and the US. The varying academic backgrounds were also notable: while most were trained as economists, a few came from the fields of law, urban planning and public administration.

In view of this composition, it comes as no surprise that the presentations covered a wide range of topics, ranging from brownfield ${ }^{5}$ redevelopment in China (Ai and Luan, 2008) and legal institutional evolution (Huang, 2008) to foreign aid (Sato, 2008; Kangoye, 2008) and comparative constitutional histories (Cordeiro, 2008). In the face of such a diversity of subjects it is difficult to find any sort of commonality other than two: (a) the implicit or usually explicit importance that is attributed to institutions, whether as a determinant of some other variable deemed to be important or as a primal object of analysis itself; and (b) the language of the discourse, which is couched in the jargon of economics, thereby reinforcing its status as the queen of the social sciences.

The methodologies employed by the scholars were also varied. Some relied on game-theoretic modeling, such as Huang (2008) in her paper that dealt with the transition occurring in a society from relations-based 'contracting' to actual legal contracts. Elements of game theory were also used in the papers of Li (2008), examining pre- and post-payment in restaurants, and Zhong and Shen (2008), studying small and medium-scale state-owned enterprises in China. Andrade (2008) fruitfully used microeconometric techniques to examine the impact of a court decentralisation programme on women's well-being in Peru. Econometrics was also a principal tool of choice for Lim (Decker and Lim, 2008): using crosssection and panel datasets, they examined whether democracies grew faster than non-democracies. Du and Ye (2008) discussed incentive contracts in a mixed

\footnotetext{
5 A brownfield is a piece of land that used to serve an industrial or some other commercial purpose and is contaminated by pollutants or hazardous waste.
} 
duopoly setting where they drew results from an experimental model. Other researchers did not use traditional economic techniques. ${ }^{6}$

Multiplicity in the choice of methodology is possible at very few conferences organised by economists. So far, it has only been the sub-discipline of economics called New Institutional Economics (NIE) that has completely embraced an interdisciplinary approach to studying social phenomena. While, for example, the economics of crime incorporates ideas from psychology and sociology, and behavioural economics from (yet again) psychology and neuroscience, NIE invites input from scholars from all of the above, including - but not limited to political science, law, anthropology, finance, geography and history.

The faculty lectures spanned a wide range of topics. Mahbubani (2008) gave an inaugural lecture on the challenges of global governance. Neo (2008) presented the success story of Singapore's adaptive education policy and its Ministry of Education. The limits of risk management in an age of rapid financial innovation were discussed by Mohrman (2008), while Araral (2008) talked about the institutional dynamics that govern small and medium-scale irrigation infrastructure in the Philippines. Simpser (2008a) discussed the unintended consequences of election monitoring. He also gave a second presentation (Simpser, 2008b) which elaborated on a theory of corrupt elections. Gehlbach presented a coauthored paper (Gehlbach et al. 2008) on the impact of the size of state bureaucracy on the effectiveness of privatisation in post-communist Russia. Florini (2008) talked about the role of global institutions in the context of managing climate change. Shirley (2008) gave an overview of the broad topic of 'institutions and development'. Hill $(2008 \mathrm{a}, \mathrm{b})$ delivered a lecture on property rights in the American Old West (late 19th century) and another on water rights. Social security reform was discussed by Asher (2008). Finally, the regulation of medical licences in the US was the topic presented by Law (2008).

3.

\section{SELECTED PRESENTATIONS}

To give an indication of the quality of the papers presented during the workshop, the papers of Gehlbach, Brown and Earle (2008) and Decker and Lim (2008), representing faculty and participants respectively, are discussed below. The former was presented by Scott Gehlbach and the latter by Jamus Jerome Lim.

\footnotetext{
${ }^{6}$ For example, Cordeiro (2008), on constitutional changes, the contents of constitutions and their development impacts; Haldar (2008), providing a critical comparison of the institutional models of Nobel Peace Prize winner Muhammad Yunus and Peruvian economist Hernando de Soto; Paloyo (2008), on family-controlled corporations, private benefits of control and legal institutions; Sato (2008), on the phenomenon of donor developing countries in Asia and its implications for Japan as the principal donor country in the region.
} 


\subsection{Privatisation and bureaucracy in post-communist Russia}

The central question in the paper of Gehlbach et al. (2008) is "why have economic reforms aimed at reducing the role of the state in the economy been successful in some institutional environments but not others?' In their paper 'Helping Hand or Grabbing Hand? State Bureaucracy and Privatization Effectiveness', Gehlbach and his colleagues use a rich dataset from Russia and subject it to panel econometric techniques to draw a counterintuitive conclusion: 'Privatization has a more positive effect on firm performance in regions with relatively large state bureaucracies.'

The result is contrary to intuition because of the way bureaucrats have been characterised in economic literature, particularly in transition economies such as Russia. Gehlbach et al. (2008) note: 'To the extent that each additional bureaucrat acts as a "toll taker" whose approval is necessary to engage in private economic activity, these pathologies should be exacerbated when bureaucracies are large.' The pathologies referred to include rent-seeking behaviour which bureaucrats are expected to exhibit and which managers of private corporations face when they interact with the state. If bureaucrats are not actively engaged in rent-seeking, they may simply be incompetent - either way, bureaucratic interference (deliberate or otherwise) will likely increase the marginal cost of performance-enhancing measures planned by owners and managers of privatised corporations such that 'in the limit, [bureaucracy] might prevent any improvements from taking place.'

Gehlbach et al. (2008) observe the opposite (Table 1). Larger bureaucracies, particularly regional, executive-branch ones, actually improve the performance of privatised enterprises, as measured by the value of output net of taxes. They offer two explanations for this result and ultimately reject the former in favour of the latter: 'privatisation implementation' and 'post-privatisation business environment'. The first takes into account that the method of privatisation itself (and the resulting owners of privatised firms) may be different across regions in Russia, i.e., a 'self-selection problem' in the terminology of economists. The second focuses on differences in the prevailing business environments after privatisation across regions. The data do not support the hypothesis that differences in implementation account for the positive effect of larger regional executive bureaucracies. Using another dataset, ${ }^{7}$ however, the researchers have been able to provide some evidence that larger regional executive bureaucracies support better business environments for privatised firms. ${ }^{8}$

7 For most of their paper, Gehlbach et al. use data from the Federal State Statistics Service (Rosstat). To test the hypothesis that the post-privatisation business environment is driving their main result, they switch to data from the Business Environment and Enterprise Performance Survey (BEEPS) of the World Bank.

8 Due to data constraints, the authors note that the rejection of the 'privatisation implementation' hypothesis and the mild acceptance of the 'post-privatisation business environment' hypothesis should be taken with a grain of salt. 
Table 1: State bureaucracy and privatisation effectiveness

\begin{tabular}{|l|c|c||}
\hline \multicolumn{1}{|c|}{ Independent variable } & Estimated coefficient & Standard error \\
\hline (Log) Federal executive bureaucracy & 0.005 & 0.145 \\
\hline (Log) Regional executive bureaucracy & $0.265^{* * *}$ & 0.094 \\
\hline (Log) Bureaucracy, other branches & 0.056 & 0.112 \\
\hline (Log) Population & $-0.204^{*}$ & 0.104 \\
\hline (Log) Income per capita & -0.012 & 0.052 \\
\hline Urbanisation & $0.582^{* * *}$ & 0.173 \\
\hline Autonomous region & $0.098^{* *}$ & 0.041 \\
\hline Constant & $-1.835^{* * *}$ & 0.517 \\
\hline $\begin{array}{l}\text { Notes: } \\
\text { The dependent variable is region-specific privatisation effect. } \\
* * *, * *, \text { and * indicate statistical significant at 1, 5, and } 10 \text { percent levels, respectively. }\end{array}$ \\
\hline
\end{tabular}

Source: Gehlbach et al. (2008).

As the title of their paper suggests, the state bureaucracy can either be a 'helping hand', facilitating privatisation and profitable conduct of business, or a 'grabbing hand', stifling productivity by increasing transaction costs. They note that, at least in post-communist Russia, regional state executives offer a helping hand to private enterprises. While this is a valuable insight in and of itself, the paper falls short of answering a (perhaps) more important question: what is it that makes bureaucrats offer a helping instead of a grabbing hand? Furthermore, what makes a larger bureaucracy more conducive to private business than a smaller bureaucracy? Gehlbach et al. note that 'it appears that [the frustrations of private firms in Russia in dealing with public officials] may be smaller in regions where there are more bureaucrats with which to work', but as to why working with more bureaucrats can help rather than suppress private initiatives is unclear.

The preceding discussion does not mean to imply that the researchers are ignorant of these deficiencies. They are fully aware of the gap that must be filled. In their conclusion, they specify the next step, which is to study 'the particular mechanisms by which state bureaucracy influences privatization effectiveness, and economic reform more generally.' The question of whether the business environment in a country is conducive or deleterious is crucial in the light of what economic historians have shown: '[i]nstitutions that enabled markets underpinned economic success stories; institutions that stifled markets accomplished stagnation.' (Fabella, 2008).

\subsection{Growth and democracy}

The presentation of Jamus Jerome Lim is based on a co-authored paper (Decker and Lim, 2008). The question they pose is: what fundamentally drives growth? In 
a workshop on institutional analysis the answer is obvious: institutions. But Decker and Lim go deeper by examining what particular institutions, and - in their words - by 'unpacking' this amorphous concept. Their taxonomy of institutions consists of two parts: 'political' and 'political-economic' institutions. The first has to do with 'societal representations' (e.g., 'checks and balances, electoral rules, and federalism'); the second with those that 'govern economic norms and rules' (e.g., 'legal frameworks, bureaucratic efficacy, curbs on corruption, and regulatory burden'). This is distinct from the Northian taxonomy that classifies institutions into two types: (1) those that affect transaction costs, and (2) those that involve property rights (Fabella, 2008).

At least one of their results is controversial: democracy is neither necessary nor sufficient for development, as measured by GDP per capita. They quote the former Prime Minister of Singapore, Lee Kuan Yew, who is credited as the architect of Singapore's dramatic transformation: 'What a country needs to develop is discipline more than democracy. The exuberance of democracy leads to indiscipline and disorderly conduct which are inimical to development.' Decker and Lim (2008) point out that it is not a priori obvious that a democracy should grow faster than a non-democracy. Illustrative examples include China, Malaysia, Singapore, Tunisia, Kuwait and Bahrain. The rapid development of these countries calls into question the consensus in the Western world that democracy is part and parcel to development.

Decker and Lim reached their remarkable conclusion by subjecting a constructed panel dataset to two estimation methods: (1) by estimating a static model using an instrumental-variable approach, and (2) by estimating a dynamic model using the system generalised method of moments. The first method takes into account any endogeneity problem that is likely to arise in a regression between democracy and development. The second method is employed to properly account for dynamics in the model. Both estimates were checked for the robustness of results by changing measures and specifications, and the results from both strategies generally stand up to the tests. What was left after the battery of robustness checks are the following conclusions: (1) that democracy has no significant impact on a country's development, and (2) that political-economic institutions have a positive and significant impact on a country's development.

The danger in papers such as this lies in the policy implications that may be derived not only by the careless but, more menacingly, by the malicious. Fortunately, Decker and Lim are neither. They quote noted trade economist Jagdish N. Bhagwati: 'Democracy is not necessarily better for development. Only when

9 Interestingly, Lee Kuan Yew made this statement in a speech in Manila, the Philippines, in 1992 at the invitation of the Philippine Chamber of Commerce and Industry. He noted that an 'American-style constitution' is the brick wall between the Philippines and development (McGurn, 1993). 
combined with markets and openness does democracy offer the best prospect of achieving the efficient, dynamic society that allows development to thrive.' The point is not that non-democracies grow faster than democracies (although some do, obviously) or that democracies should surrender their ideals to an autocrat; the point is that, in development, there is a persistent issue of sequencing. Perhaps non-democracies should pursue other things first, such as enforcement of property rights, before representation in Congress (or Parliament, if one prefers). The question of what poor democracies should do - and in this respect countries like the Philippines come to mind - is left unanswered. However, it seems that democratic ideals are still highly regarded, even by those who find that democracy is inconsequential for development:

While it is tempting to claim the policy implication that promoting democratic development is therefore irrelevant, doing so would disregard the tremendous value afforded - in terms of individual freedom and political representation by democracy per se. It seems unwise to substitute such intangibles in favor of growth, at any cost. (Decker and Lim, 2008)

\section{CONCLUSION}

An observation often made during the workshop, attributed to John V.C. Nye of Washington University at St. Louis by Mary M. Shirley, is that 'we are all institutionalists now'. This is a testament to the pervasiveness of New Institutional Economics in the study of development. Twenty-five years ago, 'North and his coworkers were flirting with heresy' (Fabella, 2008). Now, very little doubt remains (if any at all) about the claim that the fundamental driver of growth is institutions.

Asia is a region where the sharp divide between countries with 'good' institutions and those with 'bad' ones could not be more vivid, especially if we consider starkly opposing countries like the Philippines and Singapore. While the latter has leapfrogged over everybody else in the region, '[the Philippines'] march to the bottom of the Asian league continues' (Fabella, 2008). The magnitude of the difference is amplified when one considers the fact that, about 55 years ago, Singapore was a 'riot-ridden, malaria-infested tropical island (Decker and Lim, 2008) while the Philippines was next only to Japan in terms of real gross domestic product (RGDP) per capita ${ }^{10}$ (Heston et al., 2006). In 2007, Singapore's RGDP

10 Note that Singapore was not yet independent at that time, so we compare the Philippines and Malaysia. If one compares the Philippines with Singapore in 1960 (the earliest year for which the Penn World Table has data for that country), Singapore has about double the RGDP per capita. 
per capita stood at US $\$ 48,900$, which is almost 15 times larger than the Philippines' US\$ 3,300 (CIA, 2008).

The difference lies in institutions. While it is true that proximate causes ${ }^{11}$ of growth have remained significant in standard growth regressions by economists, recent work, as exemplified by the participants during the workshop, has instead focused on the social fabric upon which markets rest. Much of the work over the last 30 years has 'reaffirmed Adam Smith's faith in the market and private initiative as the engine of growth [but] North and [his] co-workers revealed [that] the shafts and cylinders of that market engine' are made up of institutions (Fabella, 2008). Another economist notes that institutions matter so much 'that not paying attention to institutions, said [John] Nye, is like missing the economic forest for the statistical trees' (Collas-Monsod, 2008).

Table 2: Expatriate perceptions of corruption in Asia

\begin{tabular}{|l|c|c|c|}
\hline \multicolumn{1}{|c|}{ Territory } & $\mathbf{2 0 0 6}$ & $\mathbf{2 0 0 7}$ & $\mathbf{2 0 0 8}$ \\
\hline China & 7.58 & 6.29 & 7.93 \\
\hline Hong Kong & 3.13 & 1.87 & 1.80 \\
\hline India & 6.76 & 6.67 & 7.25 \\
\hline Indonesia & 8.16 & 8.03 & 7.98 \\
\hline Japan & 3.01 & 2.10 & 2.25 \\
\hline Macau & 4.78 & 5.18 & 3.30 \\
\hline Malaysia & 6.13 & 6.25 & 6.37 \\
\hline Philippines & 7.80 & 9.40 & 9.00 \\
\hline Singapore & 1.30 & 1.20 & 1.13 \\
\hline South Korea & 5.44 & 6.30 & 5.65 \\
\hline Taiwan & 5.91 & 6.23 & 6.55 \\
\hline Thailand & 7.64 & 8.03 & 8.00 \\
\hline Vietnam & 7.91 & 7.54 & 7.75 \\
\hline Average & 5.81 & 5.78 & 5.77 \\
\hline $\begin{array}{l}\text { Notes: } \\
\text { Grades range from } 0 \text { to } 10, \text { with } 10 \text { as the worst. }\end{array}$ & \\
\hline Source: Pabico & & \\
\hline
\end{tabular}

Source: Pabico (2008).

It should be obvious that for institutions to propel growth, they must function well. On the one hand, thanks to the Americans, 'Filipinos were electing the lower house of a bicameral national legislature as early as 1907, and then began electing the upper house in 1916' (Nelson, 2007). As Asia's oldest democracy,

11 By this, we mean capital stock, infrastructure and a similar assortment of other metrics. 
what does the Philippines have to show for it? 'The country is a pit of institutional dysfunction' (Fabella, 2008). On the other hand, Singapore, which ranks 141st among 169 countries in the 2007 edition of the Press Freedom Index of Reporters sans Frontières (the Philippines is ranked 128th), has one of the lowest crime rates in the world and corruption in government and the rest of the civil service is virtually unheard of. In a survey of expatriate businessmen's perception of corruption in the region conducted by the Hong Kong-based Political and Economic Risk Consultancy, Singapore has consistently outperformed other countries since the survey was initiated in 1997 (Pabico, 2008). In the past two years, the Philippines has been viewed as the most corrupt country, overtaking Indonesia in 2007 (Table 2). This has led some commentators to say that 'what the Philippines has is not a democracy but a vote' ${ }^{12}$ (McGurn, 1993).

Lessons from the Asian experience can have wide applicability elsewhere. The RCI recognises this and, two months after its first workshop in Asia, held a second one in Los Baños, the Philippines, in partnership with the Philippine Economic Society, the Southeast Asia Regional Centre for Graduate Study and Research in Agriculture, and the Friedrich Naumann Foundation. No doubt, another group of researchers will benefit from the focus on institutional analysis afforded by this workshop. Economists and other scholars from allied fields would be remiss if they failed to incorporate the impact of institutions into their study of development.

\section{References}

Ai Dong and Luan Sheng Ji, Regulatory Commons Problem of Brownfields Redevelopment in China: A Framework of Institutional Analysis, presentation at the RCI Workshop (2008).

Andrade, Raul, Court Decentralization and Women's Well-Being, Presentation at the RCI Workshop (2008).

Ang, Alvin, Determining the Social Costs of Overseas Filipino Workers' Remittances: A Need for Better Regulation and Institutional Arrangements, presentation at the RCI Workshop (2008).

Araral, Eduardo, Research on Institutions for Collective Action, presentation at the RCI Workshop (2008).

Asher, Mukul, The Role of Institutions in Social Security Reform, presentation at the RCI Workshop (2008). $1993)$.

12 'Yeltsin had his vote, too. Would anyone confuse Russia with a democracy?' (McGurn, 
Benham, Alexandra, Communicating Institutional Findings, presentation at the RCI Workshop (2008).

Benham, Alexandra and Lee Benham, Formulating Research Projects, presentation at the RCI Workshop (2008).

Central Intelligence Agency (CIA), CIA World Factbook (Washington D.C., USA 2008).

Collas-Monsod, Solita, Get Real: 'Mutant Gene' (2008), available at INQUIRER. net: <http://www.opinion.inquirer.net/inquireropinion/columns/view/2008031 5-124810/Mutant-gene>.

Cordeiro, Jose, Comparative Constitutional History of Latin American and East Asian Countries, presentation at the RCI Workshop (2008).

Decker, Jessica and Jamus Lim, What Fundamentally Drives Growth? Revisiting the Institutions and Economic Performance Debate (2008), available at $<\mathrm{http}: / /$ www.jamus.name/research/ipe2.pdf $>$.

de Dios, Emmanuel, A Message to Alumni, speech at the University of the Philippines, School of Economics, Alumni Homecoming (2007), available at $<$ http://www.econ.upd.edu.ph/othercontents/dean_message_to_upsealumni_se p_15.pdf $>$.

Du Ninghua and Ye Guangliang, Incentive Contracts in a Mixed Duopoly: An Experimental Study, presentation at the RCI Workshop (2008).

Fabella, Raul, Douglass North and the Crisis of Institutions (2008), available at INQUIRER.net: <http://www.opinion.inquirer.net/inquireropinion/talkofthetown/ view/20080315-124940/Douglass-North-and-the-crisis-of-institutions $>$.

Florini, Ann, Global Institutions, presentation at the RCI Workshop (2008).

Gehlbach, Scott, David Brown and John Earle, Helping Hand or Grabbing Hand? State Bureaucracy and Privatization Effectiveness (2008), available at $<$ http://www.papers.ssrn.com/sol3/papers.cfm?abstract_id=1194702>.

Halder, Antara, On Implementing Institutions: de Soto and Yunus Compared, presentation at the RCI Workshop (2008).

Heston, Alan, Robert Summers and Bettina Aten, Penn World Tables Version 6.2 (Center for International Comparisons of Production, Income and Prices at the University of Pennsylvania 2006).

Hill, Peter, The Not-So-Wild West: Property Rights on the Frontier, presentation at the RCI Workshop (2008a).

Hill, Peter, Water Rights, Presentation at the RCI Workshop (2008b).

Huang Fali, The Transition from Relational to Legal Contract Enforcement, presentation at the RCI Workshop (2008).

Kangoye, Thierry, Foreign Aid, External Macroeconomic Instability, and the Quality of Institutions, presentation at the RCI Workshop (2008).

Kwong, Valerius, Voluntary and Imposed Racial Segregation Zoning: A CoasianOlson Hong Kong Comparative Empirical Study, presentation at the RCI Workshop (2008). 
Law, Marc, Institutional Determinants of Regulatory Enforcement: Evidence from Medical Licensing Boards in the United States, presentation at the RCI Workshop (2008).

Li Xinyu, Why Do Not All Restaurants Charge the Meal Before Eating?, presentation at the RCI Workshop (2008).

Mahbubani, Kishore, New Challenges of Global Governance, presentation at the RCI Workshop (2008).

McGurn, William, 'Asian Dilemmas: Can Asia's Managed Capitalism Keep Growing If the Countries Don't Open up Politically and Economically? But If They Do Open up, Will They Be Inviting Western-style Welfarism and Strife?', National Review (29 November 1993), available at $<$ http:://www. findarticles.com/p/articles/mi_m1282/is_n23_v45/ai_14753250>.

Mohrman, Henry, Financial Innovation and the Limits of Risk Management, presentation at the RCI Workshop (2008).

Muhamad, Tauvik and Hanafi Rais, Improving the Revenue System under Fiscal Decentralization in Indonesia, presentation at the RCI Workshop (2008).

Nelson, Robert, The Philippine Economic Mystery, UP School of Economics Discussion Paper No. 2007-09 (2007).

Neo Boon Siong, Institutional Building and Change in Singapore, presentation at the RCI Workshop (2008).

Neo Boon Siong and Geraldine Chen, Dynamic Governance: Embedding Culture, Capabilities and Change in Singapore (Singapore, World Scientific Publishing Co. Pte. Ltd. 2007).

North, Douglass, Economic Performance through Time, Prize Lecture (Nobel Foundation 1993), available at <http://www.nobelprize.org/nobel_prizes/eco nomics/laureates/1993/north-lecture.html $>$.

Pabico, Alecks, 'A Closer Look at the 2008 PERC Survey, The Daily PCIJ (2008), available at $<$ http://www.pcij.org/blog/?p=2264>.

Paloyo, Alfredo, Family Ties: Corporate Ownership Concentration and Legal Institutions, presentation at the RCI Workshop (2008).

Qian Jiwei, An Essay on Chinese Health Reform and Local Government, presentation at the RCI Workshop (2008).

Sato, Jin, Emerging Donors in Asia and Their Implications for Japan's Foreign Aid Policies, presentation at the RCI Workshop (2008).

Shirley, Mary, Institutions and Development, presentation at the RCI Workshop (2008).

Simpser, Alberto, Measuring Things That Are Hard to Measure, presentation at the RCI Workshop (2008a).

Simpser, Alberto, The Subversion of Institutions for Electoral Purposes, presentation at the RCI Workshop (2008b).

Tsui, Kevin, Resource Curse? A Theory of Contestable Political Market with Endogenous Entry Barriers, presentation at the RCI Workshop (2008). 
Wang Hai, Why Are the State-Owned Enterprises in China Always Sold by Negotiations?, presentation at the RCI Workshop (2008).

Wong Siu Wai, Tang Bo Sin and Liu Sing Cheong, Why Value-Based Property Taxation Cannot Happen in Transitional Urban China, presentation at the RCI Workshop (2008).

Yang Yi, Social Ties and Internal Knowledge Transfer: Does Culture Matter?, presentation at the RCI Workshop (2008).

Zhao Yang and Fang Ying, Do Institutions Matter? Estimating the Effects of Institutions on Economic Performance in China, presentation at the RCI Workshop (2008).

Zhong Ninghua and Shen Ji, An Evolutionary Game Model for China's Mediumand Small-Scale State-Owned Enterprise Reform, presentation at the RCI Workshop (2008). 